\title{
David Oliver: Will the public use alternatives to emergency departments?
}

\author{
David Oliver consultant in geriatrics and acute general medicine
}

Berkshire

I've argued before that we shouldn't blame the public for using emergency departments, ${ }^{1}$ as has a joint observational study from the Royal College of Emergency Medicine and the Patients Association. ${ }^{2}$ The position was that urgent need is defined by service users in real time. The public are intelligent consumers who go where the lights are on, and many are in any case directed to acute hospitals by NHS emergency numbers.

But I'm always prepared to reflect and reconsider. A study in January of emergency department attenders at North Middlesex University Hospital has made me wonder. ${ }^{3}$ Researchers examined 37000 pieces of data and interviewed 630 patients, seeking to determine what brings patients to emergency departments even for conditions that aren't life threatening. I know that it's only one unit, in a deprived part of London, with a young, multicultural population, but here are the headlines.

More than a third of interviewees reported being aware of alternative services, such as pharmacists, NHS 111, GP extended access hubs, and urgent care centres, including one based on the hospital site. Around half (rising to three quarters at weekends) had come to the emergency department because it offered a convenient way to see a healthcare professional 24/7, even if that meant waiting. A similar proportion said that they would happily use a 24/7 walk-in centre near their home, instead of the emergency department, if it provided instant access to diagnostics.

A similar study at Barnsley hospitals showed that, of 951 patients surveyed, only $22 \%$ considered their own condition an emergency. ${ }^{4}$ Their main concern was to gain reassurance that the condition was not serious.

Speed and convenience of access to services matter to patients: the latest social attitudes survey showed that these, alongside waiting times, are key reasons for declining satisfaction with the NHS. ${ }^{5}$ And it's hard to escape relentless media coverage, including many acute doctors telling it how it is-about emergency department overcrowding, stacked up ambulances, and worsening waits. ${ }^{6}$

I accept the suggestion in Bruce Keogh's review of urgent care that the patchwork of alternatives to emergency is often confusing to the public and should be simplified and more clearly communicated. ${ }^{7}$ After all, the emergency department is a strong brand, familiar to everyone.

The finite resource of NHS acute care is for the entire population, however difficult that might be for politicians

We might argue that, if the emergency department gives the public what they want, we should accept that people want to use it and will do so. But endemic staffing and space problems mean that this isn't a sensible proposition in already overcrowded departments and hospitals. Experiments with extended GP opening hours don't seem to have reduced demand convincingly. A recent analysis of GP opening hours around Europe shows that we already have longer hours of access than most countries, ${ }^{8}$ and NHS England vanguard sites focusing on urgent and emergency care have still seen growth in activity-albeit lower than at non-vanguard sites. ${ }^{9}$

Surely, we need to start saying loudly and clearly that the finite resource of NHS acute care is for the entire population, however difficult that might be for politicians. Every citizen who uses it for speed and convenience rather than the level of need risks compromising care for other citizens who might need services more. We must be realistic about what acute care is for, what it's not for, and the need for us to find more resources if we really do want $24 / 7$ direct access to specialist care.

Competing interests: See bmj.com/about-bmj/freelance-contributors/david-oliver. Provenance and peer review: Commissioned; not externally peer reviewed.

Oliver D. David Oliver: Stop blaming patients for emergency visits. BMJ 2015;351:h6119. 10.1136/bmj.h6119 26566636

2 Royal College of Emergency Medicine. Patients Association. Time to act-urgent care and A\&E: the patient perspective. May 2015. https://bit.ly/2Em5X2u.

3 North Middlesex University Hospital. New research examines patient use of North Mid emergency department. 19 March 2018. www.northmid.nhs.uk/Media/Latest-News-PressReleases/ArtMID/587/ArticlelD/173/New-research-examines-patient-use-of-North-Midemergency-department.

4 Barnsley Hospital NHS Foundation Trust. Report shows only $22 \%$ of people attending Barnsley's emergency department think it's an emergency. 7 Oct 2014. www. barnsleyhospital.nhs.uk/news/report-shows-22-people-attending-barnsleys-emergencydepartment-think-emergency/. 
5 Nuffield Trust, King's Fund. Public satisfaction with the NHS and social care in 2017 results and trends from the British Social Attitudes survey. 28 Feb 2018. https://www. nuffieldtrust.org.uk/research/public-satisfaction-with-the-nhs-and-social-care-in-2017.

6 Campbell D, Duncan P, Marsh S. NHS patients dying in hospital corridors, A\&E doctors tell Theresa May. Guardian 11 Jan 2018. https://www.theguardian.com/society/2018/jan/ 11/nhs-patients-dying-in-hospital-corridors-doctors-tell-theresa-may

7 NHS Choices. The Keogh urgent and emergency care review. 22 April 2016. https://www. nhs.uk/NHSEngland/keogh-review/Pages/urgent-and-emergency-care-review.aspx.
8 Rosenberg-Wohl S, Greenfield G, Majeed A, Hayhoe B. Seven-day access to NHS primary care: how does England compare with Europe?J R Soc Med 2018;111:88-91. 10.1177/0141076818755557 29355448

9 Minhas JS, Minhas D, Coats T, Banerjee J, Roland D. Five-year forward view: lessons from emergency care at the extremes of age. J R Soc Med 2018;111:92-7.

10.1177/0141076817744562 29171779

Published by the BMJ Publishing Group Limited. For permission to use (where not already granted under a licence) please go to http://group.bmj.com/group/rights-licensing/ permissions 